\title{
ON SOME POTTERY FORMS FROM THE BATINA-SREDNO CEMETERY FROM THE BEGINNING OF THE EARLY IRON AGE
}

\author{
Marko Dizdar - Tomislav Hršak - Daria Ložnjak Dizdar
}

DOI: https://doi.org/10.31577/szausav.2019.suppl.1.

Keywords: Batina, cemetery, Dalj Group, Early Iron Age, southern Carpathian Basin, female burial, ceramic vessels, chronology

\begin{abstract}
On some pottery forms from the Batina-Sredno cemetery from the beginning of the Early Iron Age
Batina (Kiskőszeg), on the Danube in Baranya, is one of the most significant sites in the southern Carpathian Basin from the end of the Late Bronze Age and the beginning of the Early Iron Age. For more than a century, Batina has been the source of exceptional finds which are considered to originate from destroyed funerary complexes. The collected finds helped define the chronology of the development of the Dalj Group, which marked the end of the Late Bronze Age and the beginning of the Early Iron Age in the southern Carpathian Basin. A systematic field survey was made to determine the location of the Dalj Group cemetery in Batina. Its results indicated that the cemetery could have been located in Sredno, a site south of the contemporary settlement on Gradac. This was followed by archaeological excavations in Sredno, which revealed many cremation graves of the Dalj Group containing ceramic, metal and glass finds, confirming the earlier hypotheses about the great significance of Batina as an important southern Pannonian centre from the end of the $2^{\text {nd }}$ millennium BC and the first centuries of the $1^{\text {st }}$ millennium BC, which stood on an important communication line along the Danube. The discovery of the numerous grave assemblages in Batina will enable detailed analyses of distinct pottery horizons and a better knowledge of the characteristic ceramic vessels for each distinct phase of the development of the Dalj Group.
\end{abstract}

\section{INTRODUCTION}

Batina (Kiskőszeg) in Baranya is certainly one of the most important sites from the end of the Late Bronze Age and the beginning of the Early Iron Age in the southern Carpathian Basin. For more than a century, it has been the source of many exceptional finds, which are now included in the collections of several European museums. They are metal weaponry items, horse equipment, items of costume and jewellery, and ceramic vessels probably originating from destroyed funerary complexes (Foltiny 1961; Gallus/Horváth 1939; Kossack 1954; Metzner-Nebelsick 1996, 284; 1997, 15; 2002, 28-32, 198, 595; Nad, I./Nad, P. 1964; Vinski-Gasparini 1973; Vinski/Vinski-Gasparini 1962). The variety and high number of the collected finds indicated that the settlement in Batina, located on the site of Gradac, was one of the most important centres in the southern Carpathian Basin in the late $2^{\text {nd }}$ millennium BC and the first centuries of the $1^{\text {st }}$ millennium BC. ${ }^{1}$

Batina lies on the northeast edge of Bansko Brdo, where the hill reaches the Danube. The oldest traces of settlements start in the Neolithic and continue through all the prehistoric ages, as testified by the results of many smaller trial and rescue excavations (Bojčić 1978; Bulat 1970a; 1970b; 1977; 1984; Minichreiter 1976; 1987; Pinterović 1971; Šimić 2002) and the finds collected in field surveys (Bulat 1962; 1964; 1974; 1981). Nowadays, Batina is usually evoked as one of the most important sites for the period from the end of the Late Bronze Age and the beginning of the Early Iron Age, which was marked by the development of the Dalj Group. On the basis of the results of the excavations, it is known that the Gradac site used to be a Dalj Group settlement extending over several prominent elevations ending with

1 This article has been supported in part by the Croatian Science Foundation under the project IP-06-2016-1749 Iron Age

Female Identities in the Southern Carpathian Basin (FEMINE). 
steep loess slopes and separated by deep natural ravines. The southern end of the settlement was a deep natural ravine separating it from the Sredno site, where earth mounds (tumuli) have been documented (Metzner-Nebelsick 1996, 301, fig. 1; 1997, 15; 2002, 185-187, 198, fig. 85; 87).

The Archaeological Museum in Osijek, in cooperation with the Institute for Archaeology and the Department for Archaeology of Croatian Academy of Science and Arts, started the project The Archaeological Heritage of Baranya in 2008 to record new archaeological sites and document already known sites in the area of Baranya. The project started with the field surveys of the area along the Danube from Batina to Kneževi Vinogradi, which found numerous archaeological sites of all periods (Bojčić et al. 2009; 2010). The field survey included a wide area around Batina and the northeast edge of the Bansko Brdo. Some pottery sherds found on the Gradac settlement site could be dated to the Late Bronze Age and the Early Iron Age. The finds from the Sredno site included sherds of the ceramic vessels of the Dalj Group and cremated bones, indicating the position of the cemetery. The hypothesis that Sredno included a Dalj Group cemetery was confirmed by the discovery of two cremation graves during the construction of the water supply network in 2009 (Dujmić 2011). The field survey confirmed the existence of tumuli along the settlement's single line of communications, but there were also more remote tumuli towards the eastern end of the loess plateau, as confirmed by later excavations (Hršak/Leleković/Dizdar 2013; 2015).

After completing the field surveys, trial excavations were started in autumn 2010 on the Sredno site. They found not only Roman cremation and inhumation graves, but also numerous Dalj Group cremation graves dated to the Late Bronze Age and the Early Iron Age (Bojčić et al. 2011). The subsequent continuous and systematic excavations on various locations in Sredno found numerous cremation graves of the Dalj Group. The excavation results have shown that the Dalj Group cemetery stretches from the southern edge of the natural ravine separating Sredno from the Gradac settlement; also, two explored tumuli in the northern part of the cemetery were the graves of prominent members of the community, as testified by the exceptionally complex funerary architecture and numerous prestigious finds (Hršak/Leleković/Dizdar 2013; 2014; 2015; 2016; 2017). The excavation results confirmed that Batina was one of the most important archaeological sites from the end of the $2^{\text {nd }}$ millennium $B C$

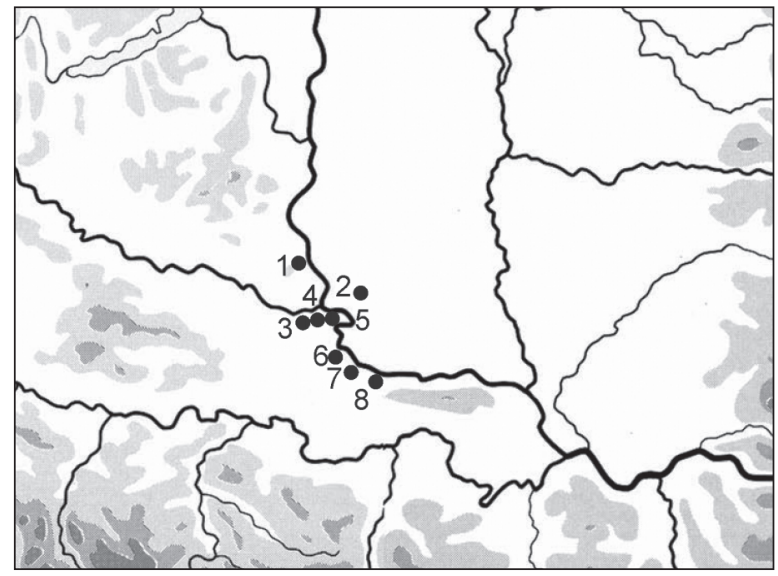

Fig. 1. Location of Batina on the Danube in the southern Carpathian Basin and other cemeteries of the Dalj Group. 1 - Batina; 2 - Doroslovo; 3 - Osijek; 4 - Dalj; 5 - Erdut; 6 - Vukovar; 7 - Sotin; 8 - Šarengrad. and the first centuries of the $1^{\text {st }}$ millennium $B C$ in the southern Carpathian Basin.

The exceptional achievement of the excavations in Batina, which have been taking place continuously until the present, is the discovery of the grave assemblages that revealed not only the characteristic pottery, but also the previously scant knowledge on the funerary rite of the Dalj Group. All the discovered graves are cremation graves, with cremated remains of the dead placed in ceramic vessels or in an organic wrapping (textile) and deposed on the bottom of the grave. Various forms of pots, usually covered by an overturned bowl, most often served as urns. There were also graves where cremated bones were put in a bowl or amphora, but such graves have been dated to the Late Bronze Age on the basis of characteristic pottery finds (Ložnjak Dizdar/Rajić Šikanjić 2016, 113-115, fig. 3). On the bottom of some grave pits, around the vessels that served as urns, there were cremated remains, probably from the pyre, containing cremated bones and burnt metal objects. Also, there were double graves, where cremated bones were deposed in different ceramic vessels.

The intercutting of graves was recorded only rarely, which probably means that they were somehow marked on the surface. The grave pits are usually rectangular or square, with rounded corners and different depths and sizes. It has been noticed that the graves of Early Iron Age date are characterised by larger and deeper pits than the graves from the end of the Late Bronze Age. The most numerous finds are ceramic vessels, which most probably contained food and drink offerings, as testified by the animal bones that were frequently found in them. The most numerous ceramic vessels are various forms of pots, bowls and kantharoi, while there are fewer jugs and cups. Exceptionally, there were double vessels 
and stands. The most frequent metal finds are items of costume (fibulae, pins) and jewellery (bracelets, torcs, pendants), which often show traces of the cremation with the dead body on the pyre. The metal objects were placed in urns together with the cremated human remains, but they have also been found within the burnt remains from the pyre. The number of metal items of costume and jewellery is bigger in the graves of women, which also contain glass beads, bone pendants, and ceramic spindle whorls. The graves of women also contained smaller iron knives with a slightly curved blade and a short tang. The graves of men are characterised by items of costume (pins) and whetstones and iron beads, along with exceptional finds of weaponry and horse equipment.

The typo-chronological analysis of ceramic and metal finds from the explored graves has shown that the Dalj Group graves found on Sredno can be divided into two horizons: an older one from the Late Bronze Age (the younger phase of the Urnfield culture) and a younger one from the beginning of the Early Iron Age. Still, the largest number of the found graves belongs to the younger burial phase, i.e. to the initial phases of the Early Iron Age (ceramic horizons IIIa, b-IV). The graves from this burial phases are characterised by large and sometimes deep pits, and the most numerous pottery finds are large pots with a biconical body serving as urns, pots with a conical neck which are often decorated with vertical fluting and ribs, bowls with a spherical body and horizontally fluted inverted rim, and kantharoi decorated with ornaments organised into metopes (Metzner-Nebelsick 1996, 301, fig. 5; 11; 14; 2002, 169-175, fig. 74-76). The explored Early Iron Age graves from the Sredno site have good parallels in earlier Dalj Group finds from Batina (Metzner-Nebelsick 1996; 2002; 2017a; 2017b; Nađ, I./Nađ, P. 1964; Vinski/Vinski-Gasparini 1962). Still, the discovery of graves with clear contexts is exceptionally important for future research of the transition from the Late Bronze Age to the Early Iron Age in the southern Carpathian Basin, characterised by the appearance of iron objects and by significant social changes and communication networks.

One of the grave assemblages representing the younger, Early Iron Age, burial phase on Sredno, is grave 44 which was found during the 2010 excavations in the eastern part of trench 2. Along with some pottery forms characteristic of the Dalj Group, grave 44 contained other forms that are not so frequent, either in Batina or in other contemporary cemeteries of the Dalj Group such as Doroslovo, Dalj or Vukovar (Fig. 1).

\section{GRAVE 44}

Grave 44 (SU 172/173), with a dark brown fill (10YR 4/6), had a rectangular pit with rounded edges, measuring $1.20 \times 0.89$ m (Fig. 2; 3), where five ceramic vessels were found (Fig. 4). The northwestern corner of the grave pit contained a pot with a spherical body, low conical neck, and slightly everted rim (Pl. I: 1). The pot's shoulder has wide warts. Two opposite places in the lower body have downwardturned tongue handles. The pot contained the cremated bones of a woman with charcoal, probably the remains from a pyre. The prong of an iron rivet was among the cremated bones. The pot was probably covered by a bowl with a spherical body (Pl. I: 2) that was found in fragments next to the pot. The northeastern corner of the grave contained a pot with a biconical body and conical neck leading to a funnel-shaped everted rim which is decorated with four flutes in each of the four opposite spots (Pl. II: 1). Where the neck becomes the shoulder, there are three horizontal flutes. The pot's shoulder has vertically set ribs in between metope-like decorations consisting of groups of vertical flutes alternating with a series of groups of three large round depressions (Fig. 5). On the lower body, in four opposite spots, there are downturned tongue handles. The pot contained a cup of a spherical body and slightly prominent bottom, with a strap-section handle reaching above the rim of the cup (Pl. II: 2). South of the pot, towards the central part of the grave pit, there was a kantharos with three handles, a biconical body and a conical neck leading to a slightly everted rim (Fig. 6; Pl. III: 1). The strap-section handles reach a little above the rim. There is a rosette motif under the handles, consisting of a large central depression surrounded by smaller ones. On the shoulder of the kantharos there is a metope-like decoration consisting of groups of oblique flutes alternating with a series of triangular groups of round depressions, where one triangular group is set on its base and the next one on its vertex. The body of the kantharos stands on a low cylindrical foot (Fig. 6). Moreover, the central part of the grave pit included animal bones belonging to a pig. ${ }^{2}$ The

\footnotetext{
2 During the excavations, pottery sherds and animal bones were found in the fill of the grave pit. They came into the fill when the grave was filled.
} 


\section{G 44}

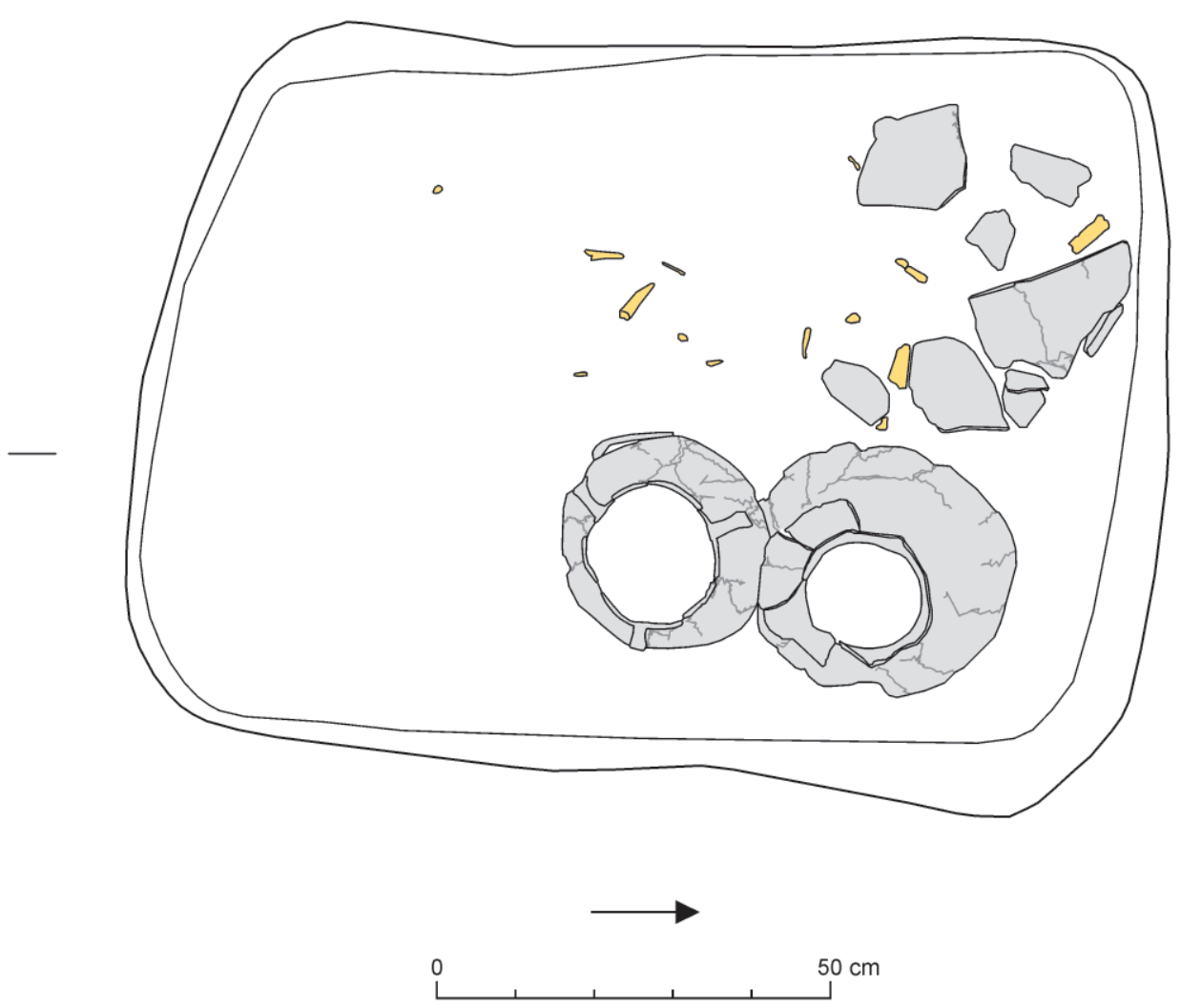

$\underline{152.92}$

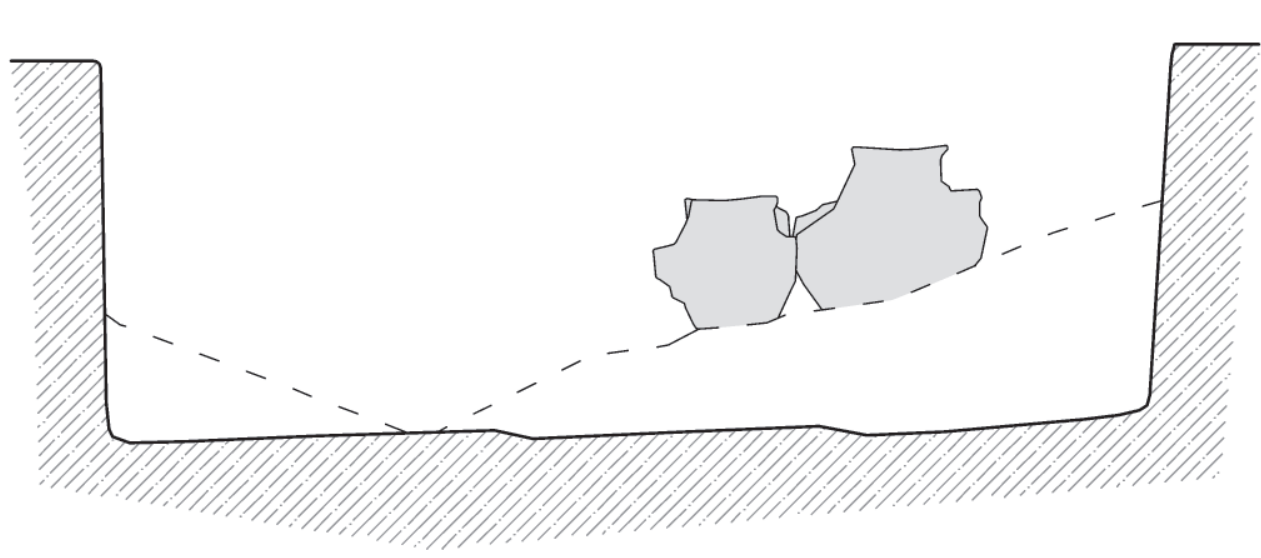

Fig. 2. Layout and cross-section of grave 44. Cremated human bones and animal bones are highlighted in yellow (made by Arheoplan Ltd for the Institute of Archaeology).

anthropological analysis of the cremated bones showed that the grave contained the remains of what was probably an adult woman. ${ }^{3}$

3 The anthropological analysis of the cremated remains of the deceased from the Batina-Sredno cemetery has been done by Petra Rajić Sikanjić from the Institute for Anthropology, while the archaeozoological analysis of the animal bones has been done by Siniša Radović from the Institute for Quarternary Paleontology and Geology of Croatian Academy of Science and Arts in Zagreb. We thank them for their cooperation. 


\section{Pot (Pl. I: 1)}

The urn in grave 44 was a pot with a spherical body and a low conical neck leading to a slightly everted rim. The pot's shoulder has wide warts, while the lower body has downturned tongue handles in two opposite spots. The pot serving as an urn from grave 44 has few parallels. In the Doroslovo cemetery, fragments of a pot with a low conical neck and tongue handles on the lower body, which also served as an urn, were found in grave 33 (Trajković 2008, 58, pl. 212: 1). The grave contained numerous ceramic vessels and items of costume and jewellery; there are three pots that stand out, decorated similarly to the second pot from grave 44 , with a combination of vertical ribs alternating with groups of horizontal round depressions or vertical fluting (Trajković 2008, 59, pl. 212:3-5). Interestingly, two pots contained a spherical cup each, similarly to grave 44 in Batina. Also, grave 33 contained a fragment of a vessel decorated with horizontal spirals produced by many tiny impressions (Trajković 2008, 59, pl. 212: $10)$, possibly dating the grave to the $8^{\text {th }}$ century $B C$, i.e. to ceramic horizon IIIa that also includes grave 32 with a similarly shaped pot (Metzner-Nebelsick 2002, 103, 172). The pots with a lower conical neck from Batina and Doroslovo, which served as urns, could represent a form predating the pots with a spherical body and low conical neck (Kragenrandgefäß), often ornately decorated with various motifs and techniques, which are most numerous in the area between Lake Balaton and the River Sava, and are dated to ceramic horizon IV (Metzner-Nebelsick 2002, 112-114, fig. 41; 2017a, 433, fig. 1).

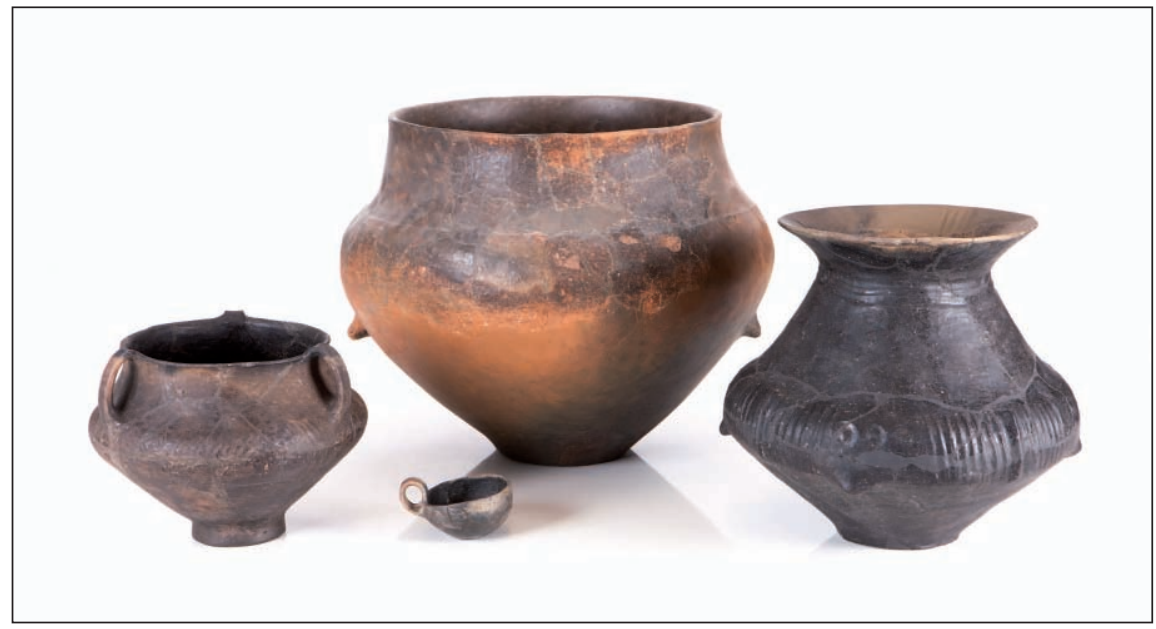

Fig. 4. Ceramic vessels from grave 44 (photo B. Jobst). served as urn lids (Trajković 2008, 16; Vasić 2008, 341). It is a simple, frequent and long-lasting form, while the bowls with a horizontally fluted rim and warts are somewhat younger, meaning that they appear starting from ceramic horizon IIIa and particularly in horizons IIIb-IV (Metzner-Nebelsick 2002, 135, 136).

Pot (Pl. II: 1)

Grave 44 produced a pot with a biconical body and taller conical neck leading to a funnel-shaped everted rim. The inside part of the rim is decorated with four flutes each in four opposite spots. There are 
three horizontal flutes where the neck becomes the shoulder. The pot's shoulder has a complex decoration consisting of several single vertical ribs alternating with a metope-like decoration consisting of groups of vertical flutes alternating with groups of three large round depressions (Fig. 5). The lower body has downturned tongue handles in four opposite spots. The pot contained a cup, which was recorded not only in Batina but also in the Doroslovo cemetery (Trajković 2008, 15, 16).

For the pot from grave 44, there are still no known parallels in the mass of finds from Batina collected long ago, as the vessels collected at the end of the $19^{\text {th }}$ century and the beginning of the $20^{\text {th }}$ century were mostly small, primarily bowls and kantharoi, which were probably found more intact, making them more interesting to the finders. The pots, being larger, were probably found in many fragments in most cases, as confirmed by more recent excavations, and did not attract the attention of local collectors. Still, parallels for the pot from grave 44, both in terms of shape and composition of decorations, can be found in other cemeteries of the Dalj Group, primarily in the nearby Doroslovo cemetery.

The mentioned grave 32 produced a pot serving as an urn, which contained not only the cremated remains of a dead woman, but also small ceramic vessels, a ceramic spindle whorl, and bronze objects. The pot's shoulder is decorated with vertical relief ribs, alternating with groups of three vertical flutes in the central part. Between each group of flutes and ribs there is a single circular depression. The pot has a conical neck at the top, decorated in three places with groups of three circular depressions, and a funnel-shaped everted rim (Trajković 2008, 57, pl. 211: 1). This pot, with

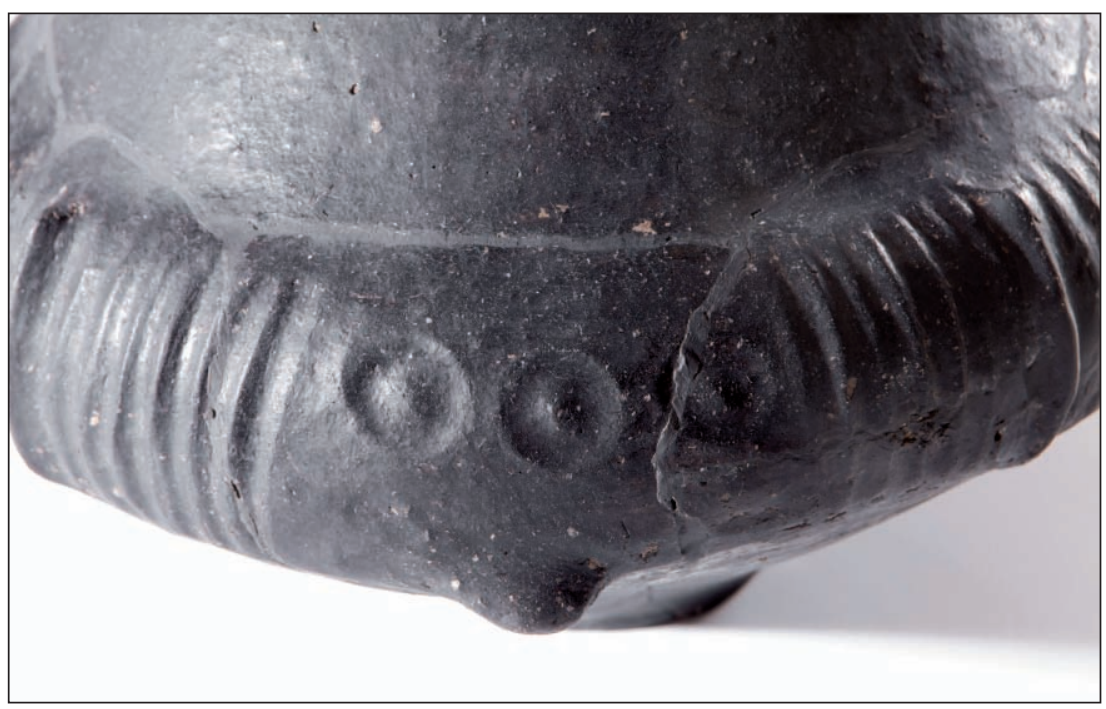

Fig. 5. Detail of a decorated pot from grave 44 (photo B. Jobst). its combination of decora-

tions of vertical ribs and groups of vertical fluting and circular depressions, shows certain formative and ornamental similarities with the pot from grave 44. Grave 32 from Doroslovo has been dated to ceramic horizon IIIa (Metzner-Nebelsick 2002, 103, 172, fig. 33). Particular importance is given to grave 33, which produced not only the mentioned urn fragments that parallel the urn from grave 44 in Batina, but also three pots decorated in a similar way. The shoulder of two pots has metope-like combinations consisting of groups of three vertical ribs alternating with groups of horizontal circular depressions. The third pot is also decorated with vertical ribs alternating with groups of vertical fluting. At the top of the conical neck, right under the funnel-shaped everted rim, there are four horizontal flutes with a series of smaller circular depressions above and below them (Trajković 2008, 59, pl. 212: 3-5). Interestingly, two pots contained a spherical cup each, similarly to grave 44 in Batina. Moreover, grave 33 produced a fragment of a vessel decorated with horizontal spirals made by many tiny impressions (Trajković 2008, 59, pl. 212: 10), probably dating the grave to the $8^{\text {th }}$ century BC. Grave 111, where an undecorated pot with a tall conical neck served as an urn, produced a pot decorated with an alternating composition of vertical ribs and groups of vertical fluting. There are another two circular depressions between the ribs and the groups of fluting. Under the everted rim, at the top of the conical neck, the pot is decorated with three horizontal flutes, while the neck is decorated with three circular depressions. The grave also produced an iron torc with hoops (Trajković 2008, 118, pl. 266: 2). Double grave 125, dated to ceramic horizon IIIb on the basis of a found pin, produced a pot decorated with two horizontal flutes at the top of the conical shoulder under the funnel-shaped everted rim. The pot's shoulder has vertical relief ribs alternating with groups of vertical fluting or two wide horizontal flutes (Trajković 2008, 132, pl. 280: 5). A similarly shaped pot from grave 126 is decorated on the shoulder with vertical ribs alternating with large circular depressions (Trajković 2008, 134, pl. 283: 3). Another grave dated to ceramic horizon IIIb was grave 137 
(Metzner-Nebelsick 2002, 175), which produced a pot with a funnel-shaped rim and three horizontal flutes at the top of the conical neck. The shoulder has vertical ribs alternating with undecorated spaces or groups of vertical shallow flutes (Trajković 2008, 150, pl. 298: 3). Grave 142 produced two pots, each containing a cup with a spherical body. The shoulder of one pot was decorated with vertical ribs alternating with groups of vertical fluting. Between the fluting and the ribs, there are circular depressions, while the ribs of the other pot alternate with groups of vertical fluting and sets of four horizontal circular depressions (Trajković 2008, 159, 160, pl. 309: 3, 5). The pot serving as the urn in the damaged grave 143 is decorated on the shoulder with vertical ribs alternating with groups of vertical flutes. Between the fluting and the ribs, there are one or two circular depressions. Moreover, the top of the conical neck of the pot is decorated with a circular depression (Trajković 2008, 160, pl. 309: 1).The Dalj cemetery also contained pottery finds that show certain similarities in form or decoration with the pot from grave 44 in Batina. The site of the Jelenik vineyard produced a pot decorated on the shoulder with groups of vertical fluting alternating with large circular depressions. There are three more horizontal flutes under the funnel-shaped everted rim (Hoffiller 1938, pl. 7: 5; Metzner-Nebelsick 2002, 671, pl. 78: 1). One of the pots from grave 9/1909 in the site of Panišić, dated to ceramic horizon IIIb, has vertical ribs on the shoulder, while the tall conical neck has circular depressions. There are horizontal flutes under the funnel-shaped rim (Hoffiller 1938, pl. 7: 1; Metzner-Nebelsick 2002, 667, pl. 65: 1). Another grave from ceramic horizon IIIb is grave 1 from Sotin, which contained three pots with a tall conical neck and a funnel-shaped everted rim. The top of their neck is decorated with horizontal fluting next to several small circular impressions. Their shoulder is usually decorated with vertical ribs, but one pot has a metope-like decoration of vertical ribs and a group of vertical flutes. Also, one of the pots contained a cup, similarly to grave 44 from Batina. The grave was dated on the basis of a bronze two-loop fibula with knots of type 6a (Ložnjak Dizdar 2010, 45, 46).

The mentioned pots with a tall conical neck from the Doroslovo cemetery were dated to the beginning of the Early Iron Age (Vasić 2008, 340, 349), meaning that the described shape of the pot (Kragenhalsgefüß) from grave 44 in Batina can probably be considered characteristic for ceramic horizon IIIb (Metzner-Nebelsick 1996, 301, fig. 11; 2002, 103, 106, 174, 175, fig. 75: 2, 3). Similar dating is indicated by the decorating technique that used the combination of vertical relief ribs, groups of vertical fluting, and round depressions, which was characteristic for the Early Iron Age phase of the Dalj Group, i.e. for the pots and kantharoi which have such metope-like decorations on their shoulder. The rosette motif under the handles of the kantharoi is considered to be a younger element (Metzner-Nebelsick 2002, 160-167, fig. $64 ; 65)$. The pots with a tall conical neck, which are decorated with horizontal fluting under the everted rim and with varied metope-like fluting on the shoulder are also characteristic for horizon II of the Poštela settlement, i.e. for the end of the $8^{\text {th }}$ and the early $7^{\text {th }}$ century BC, which should also apply to the appearance of vertical ribs on the shoulder of the pots (Teržan 1990, 32, 35, 36, 53, fig. 2: 1, 2, 5).

The pot with the tall conical neck in grave 44 from Batina shows the local ceramographic characteristics of the Dalj Group in its shape, its ornamental composition, and its combination of different decorating techniques. The continuous development of this type of pots can be clearly recognized in the appearance of ever more complex ornamental compositions during ceramic horizon IIIb.

\section{Cup (Pl. II: 2)}

The pot with the tall conical neck contained a cup with a spherical body, a slightly depressed bottom, and a strap-section handle reaching above the rim of the vessel. This form of cups has already been found in Batina (Metzner-Nebelsick 2002, pl. 22: 9; 45: 14 etc.), the Dalj cemeteries (Hoffiller 1938, 11, pl. 23: 4, 10, 12; Metzner-Nebelsick 2002, pl. 48: 5; 55: 7, 11; 64: 7, 8; 71: 10; 81: 1), Donji Grad in Osijek (Šimić 2001, 33, fig. 16), and the Lijeva Bara cemetery in Vukovar (Metzner-Nebelsick 2002, 692, pl. 110: 5; 111: 8). The Doroslovo cemetery also contained cups of a conical or spherical body with a handle that most often reaches above the rim, which were dated to the Early Iron Age (Brukner 1959, 14, 15, fig. 19; Vasić 2008, 341, 349). The handles usually have a strap cross-section, but there are twisted handles too, e.g. in grave 6 (Trajković 2008, 29, 30, pl. 183: 3; 184: 14). Graves usually contain a single cup, but there are also graves with two (e.g. graves $33,110,123$ and 142) or three cups (e.g. grave 7), often found in pots with a tall conical neck (Trajković 2008,15,16) just as in grave 44.

\section{Kantharos (Fig. 6)}

A unique pottery find from grave 44 on Sredno, which is also unique among the finds from Batina, is a vessel with three handles that probably served as a kantharos (Fig. 6). The kantharoi from the graves in 
Batina, but also from the graves in the excavated and known cemeteries of the Dalj Group, are a recognisable part of the material heritage and some of the most numerous ceramic finds in the graves.

The kantharos has a biconical body and conical neck leading to a slightly everted rim (Pl. III: 1). The handles, with a strap cross-section, reach slightly above the rim. The rosette motif under the handles consists of a large central depression surrounded by smaller ones. The shoulder of the kantharos has a metope-like decoration consisting of groups of oblique fluting alternating with triangular groups of circular depressions, where one triangular group is set on its base and the next one on its vertex. The body of the kantharos stands on a low cylindrical foot.

There are still no known parallels for the described vessel with three handles from grave 44 on Sredno. Some similarities in form and decoration can be found in the ceramic vessel defined as a pot with four handles from the princely tumulus 6 in the Kaptol-Gradci cemetery. The exceptionally rich warrior grave dated to the end of the $8^{\text {th }}$ and the beginning of the $7^{\text {th }}$ century BC contained not only weaponry, horse equipment and male costume items, but also several ceramic vessels (around 30 of them), including a pot with four handles with a strap cross-section. The vessel is taller than the one from Batina and its shoulder is decorated with groups of narrow oblique flutes forming a V-motif (Pavličić/Potrebica 2013, 25, 31, cat. no. 10).

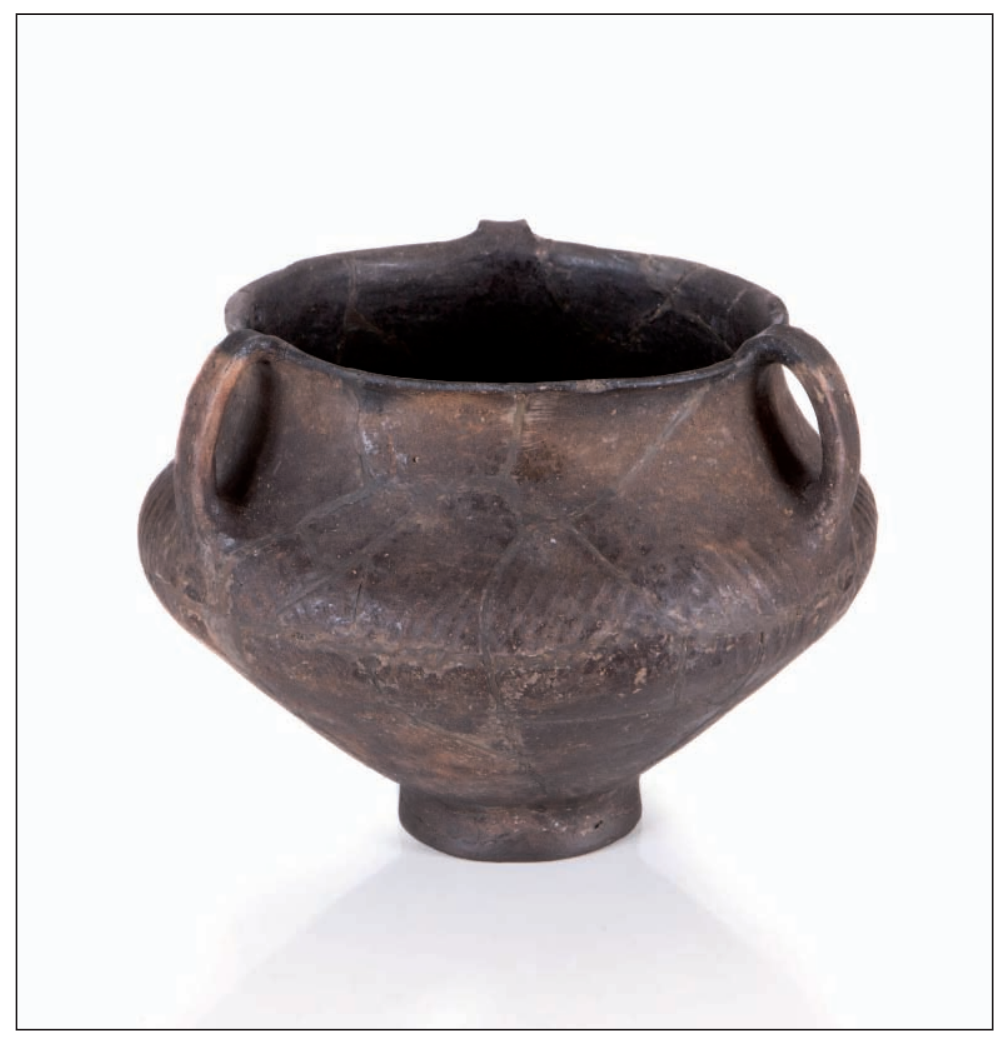

Fig. 6. Kantharoi from grave 44 (photo B. Jobst).
No kantharoi with three handles were recorded in the Doroslovo cemetery, but we can single out those decorated in a similar way with groups of oblique flutes and/or small circular depressions. Grave 92, containing the cremated remains of a dead woman with a large number of ceramic vessels, two ceramic whorls and bronze coils, and perhaps an iron spectacle fibula, produced a kantharos decorated on the shoulder with groups of vertical shallow flutes alternating with two parallel oblique grooves that have a series of small circular depressions along each side. There are two circular depressions under each handle (Trajković 2008, 105, pl. 252: 4). The grave was dated to ceramic horizon IIIb (Metzner-Nebelsick 2002, 175). Grave 134 produced a large kantharos decorated on the shoulder with groups of oblique flutes alternating with small circular depressions, and having two depressions under each handle (Trajković 2008, 146, pl. 294: 6). The kantharos from grave 138 is also decorated with groups of oblique flutes (Trajković
shoulder of the kantharos from grave 2008, 152, 301: 6). Also, there are oblique fluting decorations on the shoulder of the kantharos from grave
70/1909 in the Poštić site in Dalj, dated to ceramic horizon IIIb (Hoffiller 1938, pl. 13: 3; Metzner-Nebelsick 2002, 665, pl. 59: 7). The same dating method was used for the kantharos from grave 23/1911 in the Panišić vineyard, decorated with groups of vertical flutes (Hoffiller 1938, pl. 13: 11; Metzner-Nebelsick 2002, 667, pl. 68: 1), which appear on kantharoi much more often than the oblique flutes, as shown by the mentioned examples from the cemeteries of Doroslovo, Dalj, and Batina itself (Metzner-Nebelsick 2002, pl. 22: $5 ; 26: 2 ; 30: 12 ; 35: 1)$. The rosette or circle motifs that can be seen under the handles of the kantharoi in Batina have been recorded in Styria settlements, especially Poštela, on pots dated to horizon II and partly horizon III, i.e. the developed Ha C phase - the end of the $8^{\text {th }}$ and the first half of the $7^{\text {th }}$ century BC (Teržan 1990, 45, 53, fig. 2: 2). 
The kantharoi with the described form and decoration methods, mostly with groups of vertical flutes and circular depressions, are considered to be the characteristic form of ceramic horizons IIIb and IV (Metzner-Nebelsick 2002, 125, 174, 175, fig. 75: 9; 76: 5), where the appearance of kantharoi in graves has been dated as starting in Ha B3 already (Vasić 2008, 340, 341, 347, 349). The kantharoi in Batina and Doroslovo appear in the graves of both sexes - in fact, almost every grave has a kantharos as a grave good, sometimes even two or three of them, indicating that it was an important ceramic recipient which probably had a symbolic meaning in the funerary rite.

\section{CONCLUSION}

On the basis of the characteristic ceramic set and parallels, cremation grave 44 in the Batina-Sredno cemetery can be dated to ceramic horizon IIIb according to the classification of C. Metzner-Nebelsick (2002), i.e. to the end of the $8^{\text {th }}$ and the first half of the $7^{\text {th }}$ century BC. The combination of ceramic finds recorded in grave 44 (Fig. 4), along with the appearance of some unique forms such as the kantharos with three handles, indicates the exceptional importance of the results of the systematic excavations started in 2010 on the Sredno site, which is probably the origin of the numerous finds which are now included in the collections of several European museums. These are finds with unknown discovery contexts, which affects the possibility to date them more precisely, especially for the numerous and different ceramic vessels. Still, these finds, along with the results of new excavations, show that the Sredno cemetery, with the related settlement on Gradac, belongs to the Dalj Group, whose development marked the younger phase of the Late Bronze Age and the beginning of the Early Iron Age on the territory of eastern Slavonia, Baranya, western Bačka, and southeastern Transdanubia. Aside from the cemeteries in Dalj, Osijek, Vukovar, Sotin, and Doroslovo (Fig 1), Batina is perhaps the most important site of the Dalj Group, as testified by the numerous finds collected at the end of the $19^{\text {th }}$ and the beginning of the $20^{\text {th }}$ century, which helped, along with the mentioned cemeteries, to chronologically define the development of the Dalj Group with distinct pottery horizons (Metzner-Nebelsick 2002).

The discovery of the new grave assemblages in Batina will be an excellent complement to the distinct pottery horizons and to an even better understanding of the characteristic pottery sets for each development phase of the Dalj Group, but also to certain gender and age groups. Aside from Batina, another very important event is the publication of the results of several years of excavations in the Doroslovo cemetery in western Bačka, with valuable data about the contents of the closed funerary complexes (Trajković 2008). Of course, some pottery forms can appear in different pottery horizons, especially simpler forms such as various bowls with a spherical body and inverted rim. The difference between these two contemporary nearby cemeteries can be recognised in the numerous metal objects from the graves in Batina, which can be dated to the beginning of the Early Iron Age. Also, some of the Batina finds collected long ago indicate the existence of prominent individuals who were buried with prestigious goods, some of which had originated in faraway regions, as confirmed by the latest excavations on Sredno.

The results of the excavations in the Dalj Group cemetery at Sredno in Batina, which started in 2010 and have been continuous since then, with the discovery of a large number of funerary complexes with varied pottery sets, certainly provide a good basis for future analyses of distinct pottery horizons and a more complete understanding of the repertory of Dalj Group pottery forms and ornaments at the beginning of the Early Iron Age, as testified by some previously unknown forms such as the ones from grave 44 . 


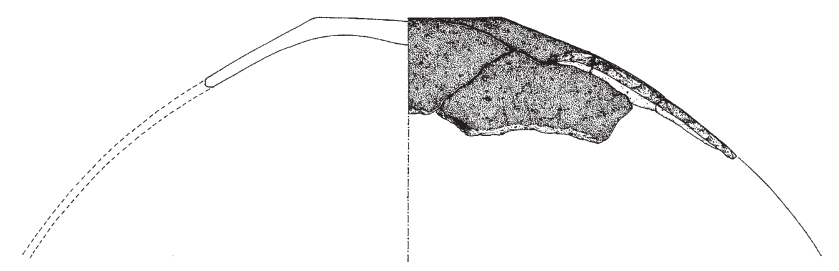

0 $15 \mathrm{~cm}$

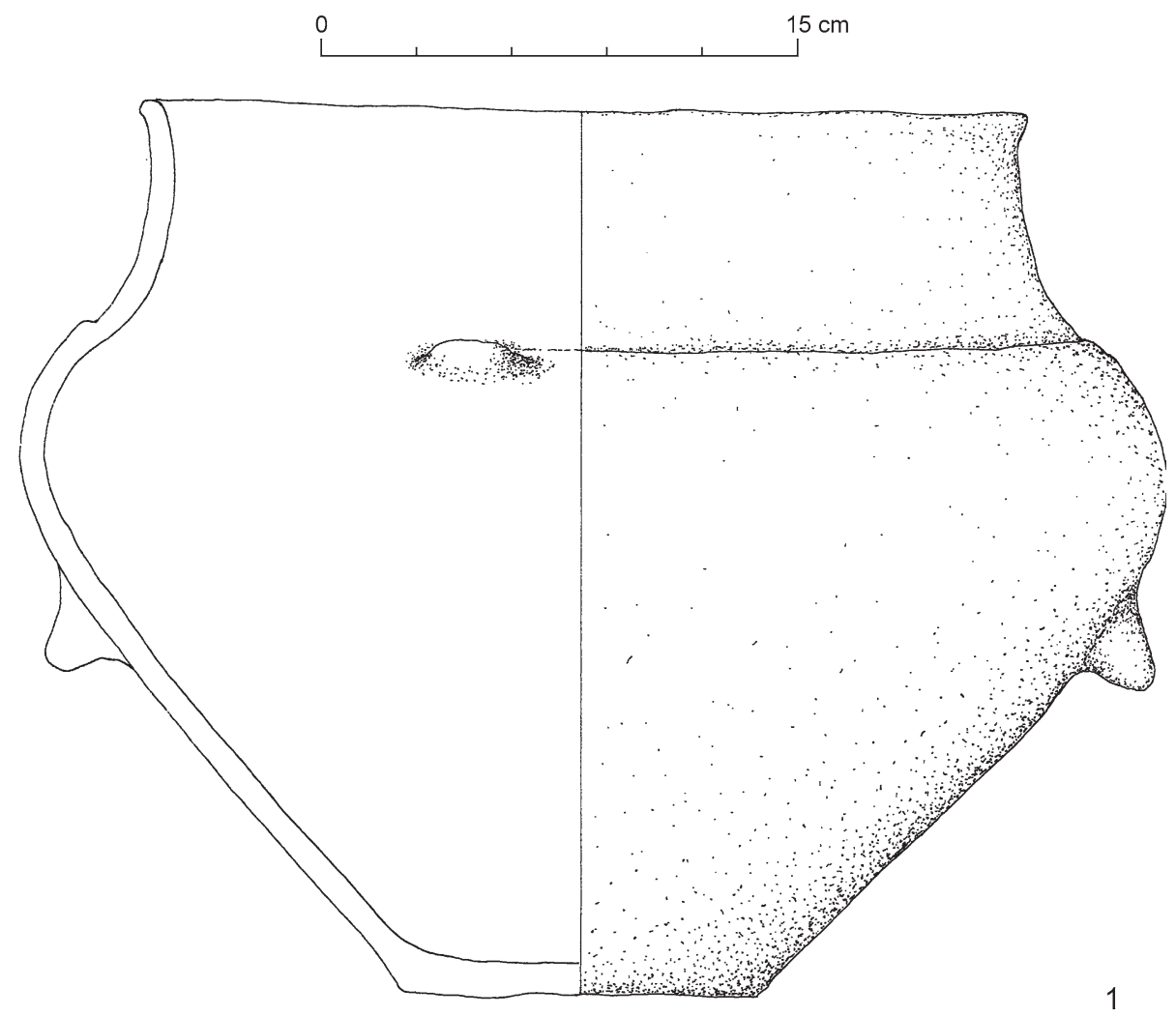

Pl. I. Grave 44 (drawing D. Radman and M. Marijanović Lešić). 


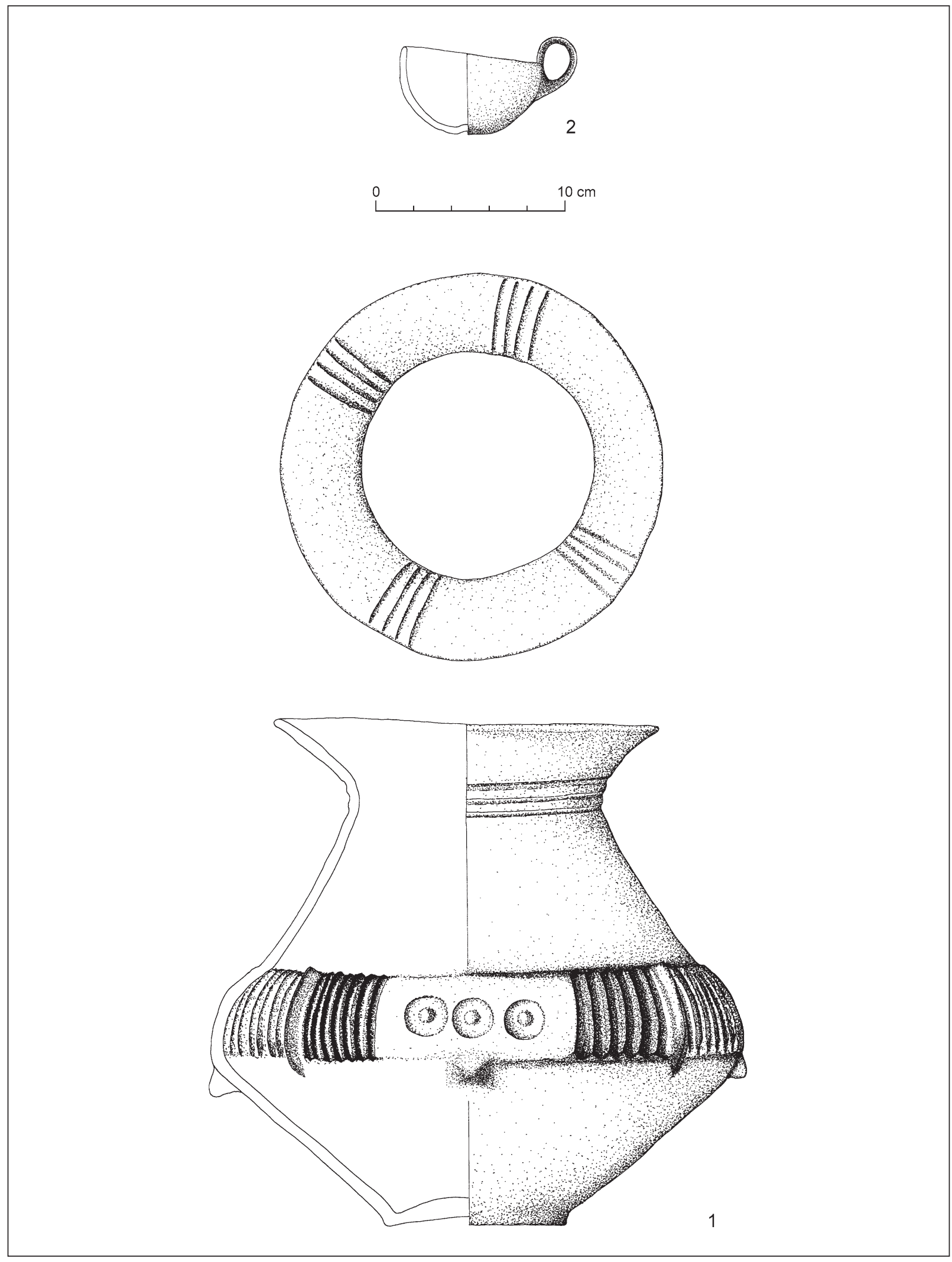



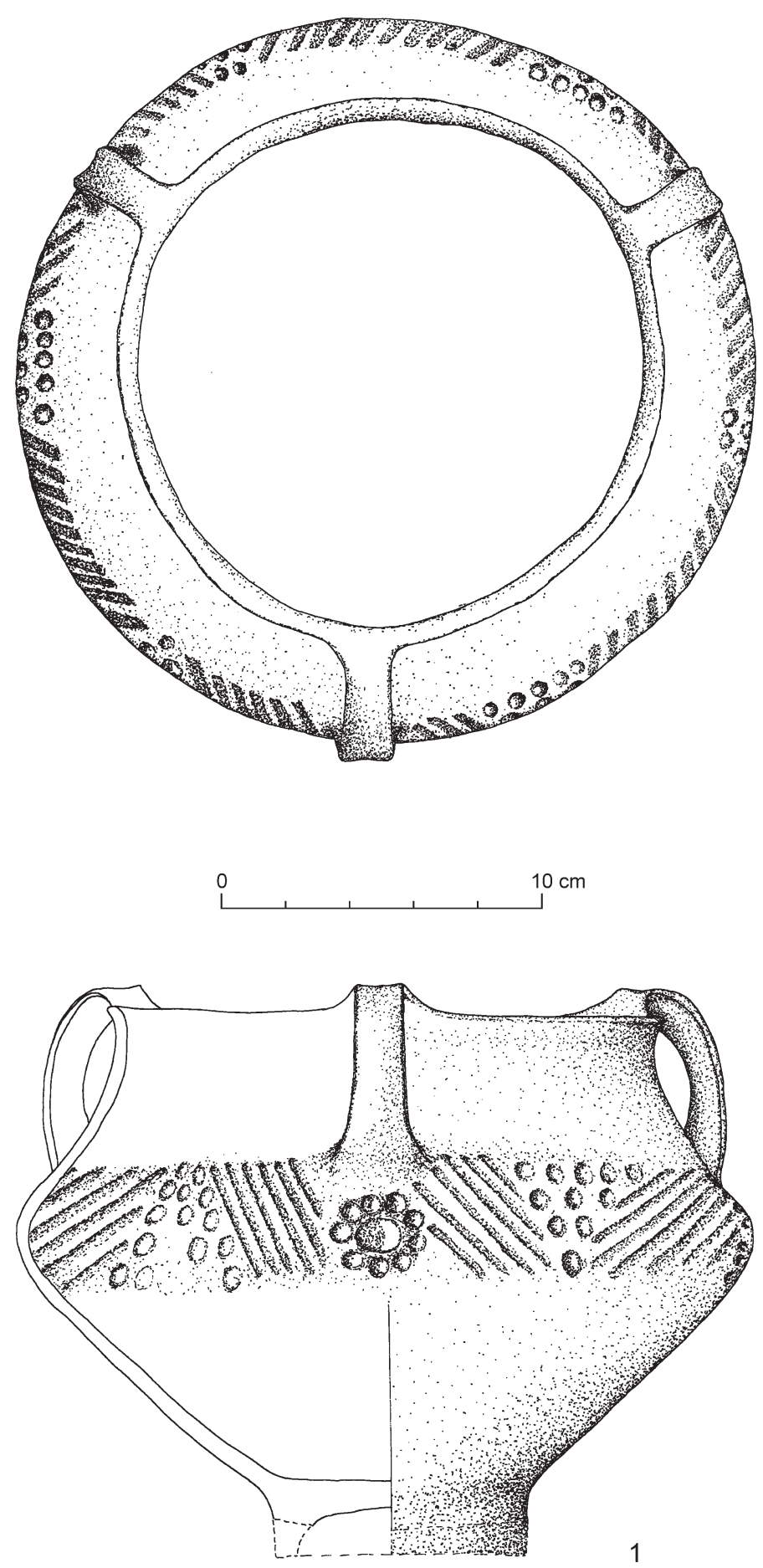

Pl. III. Grave 44 (drawing D. Radman and M. Marijanović Lešić). 


\section{REFERENCES}

Bojčić 1978

Bojčić et al. 2009

Bojčić et al. 2010

Bojčić et al. 2011

Brukner 1959

Bulat 1962

Bulat 1964

Bulat $1970 a$

Bulat $1970 b$

Bulat 1974

Bulat 1977

Bulat 1981

Bulat 1984

Dujmić 2011

Foltiny 1961

Gallus/Horváth 1939

Hoffiller 1938

Hršak/Leleković/Dizdar 2013

Hršak/Leleković/Dizdar 2014

Hršak/Leleković/Dizdar 2015

Hršak/Leleković/Dizdar 2016

Hršak/Leleković/Dizdar 2017

Kossack 1954

Ložnjak Dizdar 2010

Ložnjak Dizdar/Rajić Šikanjić 2016

Metzner-Nebelsick 1996
Z. Bojčić: Gradac, Batina - prethistorijsko nalazište. Arheološki pregled 19, 1978, 41-43.

Z. Bojčić/M. Dizdar/T. Hršak/I. Vukmanić/D. Dujmić/T. Leleković: Terenski pregled područja Batine. Annales Instituti Archaeologici 5, 2009, 125-129.

Z. Bojčić/M. Dizdar/T. Hršak/T. Leleković: Terenski pregeld područja između Batine i Suze. Annales Instituti Archaeologici 6, 2010, 80-87.

Z. Bojčić/M. Dizdar/T. Hršak/T. Leleković: Rezultati probnih istraživanja nalazišta Batina-Sredno 2010. godine. Annales Instituti Archaeologici 7, 2011, 13-19.

O. Brukner: Halštatska nekropola kod Doroslova. Građa za proučavanje spomenika kulture Vojvodine 3, 1959, 1-13.

M. Bulat: Arheološki odio: Obilasci arheološkog terena od 1. I. 1961. do 31. XII. 1962. i važnije prinove. Osječki zbornik 8, 1962, 364-368.

M. Bulat: Rekognosciranje limesa između Batine Skele i Iloka. Arheološki pregled 6, 1964, 63, 64 .

M. Bulat: Gradac, Batina skela - naselje od srednjobrončanog do željeznog doba i rimski logor. Arheološki pregled 12, 1970, 42, 43.

M. Bulat: Najnovija istraživanja u Batini Skeli. Glasnik Slavonskih Muzeja 5, 1970, $17,18$.

M. Bulat: Rekognosciranja prethistorijskih lokaliteta u Slavoniji. Arheološki pregled 16, 1974, 152-154.

M. Bulat: Stanje istraživanja antičkih naselja u Slavoniji. Materijali Saveza arheoumloških društva Jugoslavije 13, 1977, 63-91.

M. Bulat: Rekognosciranja Arheološkog odjela Muzeja Slavonije. Arheološki pregled 22, 1981, 181-187.

M. Bulat: Neki noviji antički nalazi iz Slavonije i Baranje. Izdanja Hrvatskog arheološkog društva 9, 1984, 117-128.

D. Dujmić: Dva žarna groba iz Batine. Osječki zbornik 30, 2011, 59-72.

S. Foltiny: Über die Fundstelle und Bedeutung der angeblich aus Kisköszeg stammenden hallstattzeitlichen Bronzen des Römisch-Germanischen Zentralmuseums in Mainz. Jahrbuch des Röhmisch-Geramisches Zentralmuseums Mainz 8, 1961, 175-189.

S. Gallus/T. Horváth: Un peuple cavalier préscythique en Hongrie. Trouvailles archéologiques du premier âge du fer et leurs relations avec l'eurasie. Dissertationes Panonicae Serie II/9. Budapest 1939.

V. Hoffiller: Dalj. Corpus Vasorum Antiquorum. Fascicule 2. Beograd 1938.

T. Hršak/T. Leleković/M. Dizdar: Rezultati istraživanja nalazišta Batina - Sredno 2012. godine. Annales Instituti Archaeologici 9, 2013, 12-19.

T. Hršak/T. Leleković/M. Dizdar: Rezultati istraživanja nalazišta Batina - Sredno 2013. godine. Annales Instituti Archaeologici 10, 2014, 14-20.

T. Hršak/T. Leleković/M. Dizdar: Rezultati istraživanja nalazišta Batina - Sredno 2014. godine. Annales Instituti Archaeologici 11, 2015, 18-22.

T. Hršak/T. Leleković/M. Dizdar: Rezultati istraživanja nalazišta Batina - Sredno 2015. godine. Annales Instituti Archaeologici 12, 2016, 14-18.

T. Hršak/T. Leleković/M. Dizdar: Rezultati istraživanja nalazišta Batina - Sredno 2016. godine. Annales Instituti Archaeologici 13, 2017, 40-45.

G. Kossack: Studien zum Symbolgut der Urnenfelder- und Hallstattzeit Mitteleuropas. Römisch-Germanischen Forschungen 20. Berlin 1954.

D. Ložnjak Dizdar: Sotinska groblja u željeznom dobu. In: Arheološke spoznaje o Sotinu. Rezultati probnih istraživanja 2008-2010. Exibition Catalogue. Gradski muzej Vukovar. Vukovar 2010, 24-28.

D. Ložnjak Dizdar/P. Rajić Šikanjić: Funerary Practices at the End of the Late Bronze Age in the southern Middle Danube Region. In: V. Sîrbu/M. Jevtić/K. Dmitrović/M. Ljuština (eds.): Funerary Practices during the Bronze and Iron Ages in Central and southeast Europe. Proceedings of the $14^{\text {th }}$ International Colloquium of Funerary Archaeology in Cačak, Serbia, 24 $4^{\text {th }}-27^{\text {th }}$ September 2015. Beograd Čačak 2016, 109-126.

C. Metzner-Nebelsick: Die Urnenfelder- und Hallstattzeit in Südostpannonien - eine Region im Spannungsfeld zwischen Osthallstattkreis, karpatenländischbalkanischer Eisenzeit und Steppenkultur. In: E. Jerem/A. Lippert (Hrsg.): Die Osthallstattkultur. Akten des Internationalen Symposiums, Sopron 1994. Archaeolingua 7. Budapest 1996, 283-314. 
Metzner-Nebelsick 1997

Metzner-Nebelsick 2002

Metzner-Nebelsick 2017a

Metzner-Nebelsick 2017 b

Minichreiter 1976

Minichreiter 1987

Nađ, I./Nad, P. 1964

Pavličić/Potrebica 2013

Pinterović 1971

Šimić 2001

Šimić 2002

Teržan 1990

Trajković 2008

Vasić 2008

Vinski-Gasparini 1973

Vinski/Vinski-Gasparini 1962
C. Metzner-Nebelsick: Hallstattzeitliche Zentren in Südostpannonien. Zalai Múzeum 8, 1997, 9-26.

C. Metzner-Nebelsick: Der „Thrako-Kimmerische“ Formenkreis aus der Sicht der Urnenfelder- und Hallstattzeit im südöstlichen Pannonien. Vorgeschichtliche Forschungen 23. Rahden/Westf. 2002.

C. Metzner-Nebelsick: Sumptuous Vessels and Animal Protomes - New Finds of the Early Hallstatt Period in Southeast Pannonia. In: E. Miroššayová/Ch. Pare/S. Stegmann-Rajtár (Hrsg.): Das nördliche Karpatenbecken in der Hallstattzeit, Wirtschaft, Handel und Kommunikation in früheisenzeitlichen Gesellschaften zwischen Ostalpen und Westpannonien. Archaeolingua 38. Budapest 2017, 433-470.

C. Metzner-Nebelsick: At the Crossroads of the Hallstatt East. In: R. Schumann/S. Van Der Vaart-Verschoof (eds.): Connecting Elites and Regions. Perspectives on contacts, relations and differetiation during the Early Iron Age Hallstatt C period in Northwest and Central Europe. Leiden 2017, 349-379.

K. Minichreiter: Batina skela, Općina Beli Manastir - prahistorijski i antički lokalitet. Arheološki pregled 18, 1976, 37-40.

K. Minichreiter: Arheološko blago Baranje. Anali Zavoda za znanstveni rad u Osijeku 5, 1986-1987, 1987, 43-142.

I. Nađ/P. Nađ: Katalog Arheolške zbirke dr. Imre Freya. Gradski muzej Sombor. Sombor 1964.

M. Pavličić/H. Potrebica: Prikaz materijala iz kneževskog tumula 6 s nekropole Kaptol-Gradci. Exibition Catalogue. Gradski muzej Požega. Požega 2013.

D. Pinterović: Batina - praistorijski i antički nalazi. Arheološki pregled 13, 1971, 55-58.

J. Šimić: Brončano i starije željezno doba na području grada Osijeka. Osječki Zbornik 24-25, 1996-1999, 2001, 23-42.

J. Šimić: Zaštitno sondiranje na prapovijesnom nalazištu Batina-Gradac. Obavijesti Hrvatskog arheološkog društva 3, 2002, 56-59.

B. Teržan: Starejša železna doba na Slovenskem Štajerskem. Katalozi in Monografije 25. Ljubljana 1990.

D. Trajković: Đepfeld - Nekropola starijeg gvozdenog doba kod Doroslova. Gradski muzej Sombor. Sombor 2008.

R. Vasić: Doroslovo. In: Trajković 2008, 337-354.

K. Vinski-Gasparini: Kultura polja sa žarama u sjevernoj Hrvatskoj. Monografije 1. Zadar 1973.

Z. Vinski/K. Vinski-Gasparini: O utjecajima istočno-alpske halštatske kulture i balkanske ilirske kulture na slavonsko-sremsko Podunavlje. Arheološki radovi i rasprave 2, 1962, 263-293. 


\title{
Niektoré tvary keramiky z pohrebiska Batina-Sredno zo začiatku staršej doby železnej
}

\author{
Marko Dizdar - Tomislav Hršak - Daria Ložnjak Dizdar
}

\author{
Súhrn
}

Batina (Kiskőszeg) na Dunaji v Baranskej župe je jednou z najvýznamnejších lokalít z konca mladšej doby bronzovej a zo začiatku staršej doby železnej v južnej časti Karpatskej kotliny. Po viac ako storočie bola Batina zdrojom výnimočných nálezov, ktoré zrejme pochádzali zo zničených pohrebných areálov. Zozbierané nálezy pomohli stanovit’ chronológiu vývoja skupiny Dalj, charakteristickej pre koniec mladšej doby bronzovej a začiatok staršej doby železnej na juhu Karpatskej kotliny (Metzner-Nebelsick 2002).

Archeologický výskum na lokalite Batina v Sredne vykonávaný od roku 2010 odkryl mnoho žiarových hrobov skupiny Dalj, ktoré obsahovali keramické, kovové a sklenené nálezy potvrdzujúce predchádzajúce hypotézy o vel'kom význame Batiny ako dôležitého panónskeho centra z konca 2. tisícročia pred n. 1. a z prvých storočí 1. tisícročia pred n. 1., ležiaceho na dôležitej komunikácii pozdíž rieky Dunaj. Typologicko-chronologická analýza nálezov z preskúmaných hrobov ukázala, že hroby skupiny Dalj objavené v Sredne môžeme rozdelit do dvoch horizontov: staršieho z neskorej doby bronzovej (mladšej fázy kultúry popolnicových polí) a mladšieho zo začiatku staršej doby železnej. Najvyšší počet hrobov patril do mladšej fázy pochovávania, t. j. do počiatočnej fázy staršej doby železnej (keramické horizonty IIIa, b-IV). Objav hrobov s jasnými nálezovými okolnostami je obzvlášt dôležitý pre budúci výskum prechodu z neskorej doby bronzovej do staršej doby železnej v južnej časti Karpatskej kotliny, ktorý je charakteristický výskytom železných predmetov, výraznými spoločenskými zmenami a komunikačnými sieł’ami.

Jedným z hrobových celkov reprezentujúcich mladšiu fázu pochovávania v Sredne - staršiu dobu železnú - je hrob č. 44, ktorý bol objavený počas výskumu v roku 2010. Okrem keramických foriem typických pre skupinu Dalj (urna, misa, pohár) obsahoval hrob 44 aj nádobu s tromi uchami, ktorá pravdepodobne slúžila ako kantharos, čo nie je také bežné ani v Batine, ani na iných súvekých pohrebiskách skupiny Dalj, napr. Doroslovo, Dalj alebo Vukovar.

Na základe charakteristického súboru keramiky a paralel môžeme žiarový hrob 44 na pohrebisku Batina-Sredno datovat podla klasifikácie C. Metzner-Nebelsick (2002) do keramického horizontu IIIb, t. j. na koniec 8. a do prvej polovice 7. stor. pred n. 1 .

Obr. 1. Poloha náleziska Batina na Dunaji v južnej časti Karpatskej kotliny a d’alšie pohrebiská skupiny Dalj. 1 - Batina; 2 - Doroslovo; 3 - Osijek; 4 - Dalj; 5 - Erdut; 6 - Vukovar; 7 - Sotin; 8 - Šarengrad.

Obr. 2. Pôdorys a prierez hrobu 44. Kalcinované ludské kosti a zvieracie kosti sú zvýraznené žltou farbou (vypracované spoločnostou Arheoplan Ltd pre Institute of Archaeology).

Obr. 3. Hrob 44 s dolnou častou hrobovej jamy s nálezmi (foto V. Mesarić).

Obr. 4. Keramické nádoby z hrobu 44 (foto B. Jobst).

Obr. 5. Detail zdobeného hrnca z hrobu 44 (foto B. Jobst).

Obr. 6. Kantarosy z hrobu 44 (foto B. Jobst).

Tab. I. Hrob 44 (kresba D. Radman a M. Marijanović Lešić).

Tab. II. Hrob 44 (kresba D. Radman a M. Marijanović Lešić).

Tab. III. Hrob 44 (kresba D. Radman a M. Marijanović Lešić).

dr. Marko Dizdar

Institute of Archaeology

Ljudevita Gaja 32

HR - 10000 Zagreb

marko.dizdar@iarh.hr

doc. dr. Daria Ložnjak Dizdar

Institute of Archaeology

Ljudevita Gaja 32

HR - 10000 Zagreb

dldizdar@iarh.hr
Tomislav Hršak

Archaeological Museum Osijek

Trg Sv. Trojstva 1

HR - 31000 Osijek

tomislav.hrsak@amo.hr 
